\title{
Strategi Public Relations PT Kasoem Hearing Dalam Mempublikasikan Kasoem Exhibition 2018 Kepada Masyarakat Indonesia
}

\author{
Silvina Mayasari ${ }^{1}$, Mareha Puri Rahastine ${ }^{2}$, Annisa Qibtiah ${ }^{3}$ \\ 1,2,3 Universitas Bina Sarana Informatika \\ ${ }^{1}$ email: silvina.svm@bsi.ac.id \\ 2email: mareta.mpr@bsi.ac.id \\ 3email: qibtiahannisa@gmail.com
}
Cara Sitasi: Mayasari, S., Rahastine, M., \& Qibtiah, A. (2019). Strategi Public Relations PT Kasoem Hearing Dalam Mempublikasikan Kasoem Exhibition 2018 Kepada Masyarakat Indonesia. Jurnal Komunikasi, 10(1), 56-63.

\begin{abstract}
This final project aims to find out the strategies used in utilizing the digital world, in this case via Instagram and Facebook social media. Public Relations of PT.Kasoem Hearing uses Instagram and Facebook to publish the Exhibition 2018 Kasoem to customers and potential customers.The Kasoem Exhibition is a program to exhibit the entire series of hearing examinations,information on the habilitation stage after using a hearing aid and sharing stories of experiences with hearing aid users.The riset method used in this writing is a descriptive qualitative method where information obtained from direct observation techniques and in-depth interviews, then the results are stated in the form of research reports. PT.Kasoem Marketing Communications Manager PT. Becomes the guest speaker about the strategies carried out by the public relations team.The use of Instagram and Facebook is considered very effective in publishing an event. By uploading a series of events, promotions and grand prizes attract customers and prospective customers to know and participate in the event. This event was successful and can be seen from the number of visitors who attended more than the intended target. It can be concluded that Instagram social media and Facebook were able to become media to publish the 2018 Exhibition Casoem event.
\end{abstract}

Keywords: Strategy, Publication, Social Media

\section{PENDAHULUAN}

Pada era Globalisasi saat ini teknologi dan internet berkembang dengan sangat pesat di semua lini kehidupan di seluruh dunia. Pada saat ini yang paling mempengaruhi kegiatan manusia adalah teknologi informasi. Mobilitas masyarakat yang semakin padat berdampak pada gaya hidup. Internet tidak dapat dipisahkan dari kehidupan sehari - hari. Pemanfaatannya sudah lebih jauh, bukan hanya untuk berkomunikasi tetapi juga membeli barang, memesan transportasi, hingga berbisnis dan berkarya.

Perkembangan teknologi internet yang sangat pesat, telah melahirkan banyak aplikasi media sosial, serta didukung pula dengan perkembangan teknologi telepon pintar yang menyediakan berbagai macam fasilitas bagi para penggunanya. Sehingga penggunaan media sosial serta smartphone ini menjadi sangat popular dan memberikan kemudahan-kemudahan terutama dalam hal
komunikasi.Berbagai macam aplikasi media sosial yang telah diciptakan seperti Facebook, Instagram, Telegram, Twitter dan lain sebagainya semakin akrab dan begitu mudah penggunaannya untuk kalangan masyarakat, selain untuk bertukar informasi, penggunan media sosial juga memiliki peranan terhadap pemasaran dan pengenalan suatu produk atau jasa.

Instagram dan Facebook merupakan aplikasi gratis untuk berbagi foto dan video yang memungkinkan penggunanya untuk mengambil foto dan video yang selanjutnya berbagi pada layanan jejaring sosial. Media sosial ini hadir sebagai situs komunitas sosial terbesar didunia, dimana pengguna dapat berinteraksi dengan teman lainnya di daerah atau negara lain dengan dapat melihat foto yang diposting oleh pengguna. Kedua aplikasi ini sangat efektif sebagai media promosi suatu barang dan jasa 
Ketika bahasa visual mendominasi dunia internet, dari situlah para pelaku bisnis bisa memanfaatkan peluang yang terhampar di depan mata. Gaya-gaya promosi dan penyampaian informasi yang dilakukan sangat unik dan variatif. menurut laporan dari Asosiasi Penyelenggara Jasa Internet Indonesia (APJII) populasi penduduk Indonesia saat ini mencapai 262 juta orang. Lebih dari 50 persen atau sekitar 143 juta orang telah terhubung jaringan internet sepanjang tahun 2017. Melihat fenomena ini maka PT Kasoem Hearing juga ikut berpartisipasi dalam dunia internet guna mempublikasikan kegiatan-kegiatan perusahaan kepada publik. Akun resmi media sosial PT Kasoem Hearing selain menjadi media promosi, pemanfaatan media sosial juga berfungsi untuk menambah tingkat pengetahuan masyarakat Indonesia terhadap masalah gangguan pendengaran.

PT.Kasoem Hearing adalah perusahaan yang bergerak dalam bidang jasa kesehatan, dan untuk pertama kalinya mengadakan acara Kasoem Exhibition 2018. Kasoem Exhibition adalah aktivitas yang diselenggarakan untuk menunjukan nilai keunggulan yang dimiliki KASOEM berdasarkan "KEKUATAN" yang dimiliki Perusahaan. Menunjukan bagaimana Kasoem dapat memberikan 'kebahagiaan yang nyata' kepada konsumennya dan mengenal Kasoem secara keseluruhan (booth penjualan hingga service). Kebahagiaan yang nyata tersebut ditunjukkan dalam bentuk acara yang dilaksanakan selama 2 hari berturut turut dengan berbagai macam kegiatan di CTEC Indonesia yang dapat dinikmati dan berguna untuk seluruh konsumen dan keluarganya. PT.Kasoem Hearing mempublikasikan kegiatan ini salah satunya melalui akun resmi media sosialnya yaitu melalui Instagram dan Facebook.

Berdasarkan uraian diatas maka penulis ingin mengetahui lebih dalam mengenai "STRATEGI PUBLIC RELATIONS PT KASOEM HEARING DALAM MEMPUBLIKASIKAN KASOEM EXHIBITION 2018 KEPADA MASYARAKAT INDONESIA"

Dalam penelitian ini penulis menguraikan beberapa konsep yang terkait dengan penelitian, sebagai berikut:

Cutlip (Ita Suryani, 2018) mendefinisikan strategi "sebagai penentuan tujuan dan sasaran dasar jangka panjang suatu perusahaan, dan pengalokasian sumber daya yang perlu untuk melaksanakan citacita ini”.

Menurut Oliver (Ita Suryani, 2018) mendefinisikan strategi sebagai cara untuk mencapai sebuah hasil akhir: "Hasil akhir menyangkut tujuan dan sasaran organisasi.”
Bennet (Ita Suryani, 2018) menggambarkan strategi sebagai "arah yang dipilih organisasi untuk diikuti dalam mencapai misinya.” Sedangkan Mintzberg menawarkan lima kegunaan dari kata strategi, yaitu:

a. Sebuah rencana - suatu arah tindakan yang diinginkan secara sadar;

b. Sebuah cara - suatu manuver spesifik yang dimaksudkan untuk mengecoh lawan atau kompetitor;

c. Sebuah pola - dalam rangkaian tindakan;

d. Sebuah posisi-suatu cara menempatkan organisasi dalam sebuah lingkungan;

e. Sebuah perspektif - suatu cara yang terintegrasi dalam memandang dunia.

J.C Seidel (Kussanti, D. P., \& Leliana, 2018) mengatakan bahwa "Public Relations adalah proses kontinu dari usaha-usaha manajemen untuk memperoleh goodwill (itikad baik) dan pengertian dari pelanggan, pegawai, dan publik yang lebih luas”. Sedangkan Philip Lesly (Kussanti, D. P., \& Leliana, 2018) mendefinisikan Public Relations sebagai "kegiatan yang membantu organisasi dan publik-publiknya untuk saling beradaptasi”.

Menurut Yosal (Susilowati, 2018) “Publik Eksternal adalah publik yang berada di luar lingkungan organisasi seperti lembaga pemerintah,pelanggan, pemasok, bank, media atau pers dan komunitas”.

Menurut Ruslan "Publik Eksternal adalah publik umum (masyarakat). Mengusahakan tumbuhnya sikap dan gambaran publik yang positif terhadap lembaga yang diwakilinya”. (Ruslan, 2013)

Definisi media sosial menurut Puntoadi (Giantika, 2018) adalah media online partisipatif yang mempublikasikan berita, foto, video, dan podcast yang diumumkan melalui situs media sosial. Biasanya disertai dengan proses pemungutan suara untuk membuat media item menjadi populer. Media sosial dapat mengambil berbagai bentuk, termasuk forum internet, papan pesan, weblog, wiki, podcast, gambar dan video. Teknologi seperti blog, berbagi gambar, dinding posting, e-mail, instant messaging, music-sharing, pembuatan grup dan voice over IP. Beberapa Jenis aplikasi media sosial adalah Bookmarking, Content Sharing, Wiki, Flikcr, Connecting, Creating-opinion, Blog.

Instagram menurut Nisrina (Soraya, 2018) adalah sebuah aplikasi yang digunakan untuk membagibagikan foto dan video. Instagram sendiri masih merupakan bagian dari facebook yang memungkinkan teman facebook kita mem-follow akun Instagram kita. Makin populernya Instagram sebagai aplikasi yang digunakan untuk membagi foto membuat banyak pengguna yang terjun ke bisnis online turut mempromosikan produkproduknya lewat Instagram. 
Instagram merupakan salah satu media jejaring sosial yang dapat dimanfaatkan sebagai media pemasaran langsung. Melalui Instagram- lah produk barang/jasa ditawarkan dengan meng-upload foto atau video singkat, sehingga para calon konsumen dapat melihat jenis-jenis barang/jasa yang ditawarkan.

Instagram memiliki fitur-fitur yang berbeda dengan jejaring sosial lainnya, diantara sekian banyak fitur yang ada di Instagram, ada beberapa fitur yang digunakan oleh akun instagram bandung makuta dalam menjalanan komunikasi pemasarannya, fitur tersebut adalah:

1. Followers (Pengikut)

Sistem sosial di dalam Instagram adalah dengan menjadi pengikut akun pengguna lainnya, atau memiliki pengikut Instagram. Dengan demikian komunikasi antara sesama pengguna Instagram sendiri dapat terjalin dengan memberikan tanda suka dan juga mengomentari foto-foto yang telah diunggah oleh pengguna lainnya. Pengikut juga menjadi salah satu unsur yang penting, dimana jumlah tanda suka dari para pengikut sangat mempengaruhi apakah foto tersebut dapat menjadi sebuah foto yang populer atau tidak. Untuk menemukan teman-teman yang ada di dalam Instagram.

2. Upload Foto (Mengunggah Foto)

Kegunaan utama dari Instagram adalah sebagai tempat untuk mengunggah dan berbagi foto-foto kepada pengguna lainnya. Foto yang hendak ingin diunggah dapat diperoleh melalui kamera iDevice ataupun foto-foto yang ada di album foto di iDevice tersebut.

3. Kamera

Foto yang telah diambil melalui aplikasi Instagram dapat disimpan di dalam iDevice tersebut. Penggunaan kamera melalui Instagram juga dapat langsung menggunakan efek-efek yang ada, untuk mengatur pewarnaan dari foto yang dikehendaki oleh pengguna. Ada juga efek kamera tilt-shift yang fungsinya adalah untuk memfokuskan sebuah foto pada satu titik tertentu. Foto-foto yang akan diunggah melalui Instagram tidak terbatas atas jumlah tertentu, melainkan Instagram memiliki keterbatasan ukuran untuk foto. Ukuran yang digunakan di dalam Instagram adalah dengan rasio $3: 2$ atau hanya sebatas berbentuk kotak saja.

4. Efek Foto

Pada versi awalnya, Instagram memiliki 15 efekefek yang dapat digunakan oleh para pengguna pada saat mereka hendak menyunting sebuah foto. Efek tersebut terdiri dari: X-Pro II, Lomofi, Earlybird, Sutro, Toaster, Brannan, Inkwell, Walden, Hefe, Apollo, Poprockeet, Nashville, Gotham, 1977, dan Lord Kelvin. Namun tepat pada tanggal 20 September yang lalu Instagram telah menambahkan 4 buah efek terbaru yaitu;
Valencia, Amaro, Rise, Hudson dan telah menghapus 3 efek, Apollo, Poprockeet, dan Gotham dari dalam fitur tersebut.

5. Judul Foto

Setelah foto tersebut disunting, maka foto akan dibawa ke halaman selanjutnya, dimana foto tersebut akan diunggah ke dalam Instagram sendiri ataupun ke jejaring sosial lainnya. Dimana di dalamnya tidak hanya ada pilihan untuk mengunggah pada jejaring sosial atau tidak, tetapi juga untuk memasukkan judul foto, dan menambahkan lokasi foto tersebut.

6. Arroba

Seperti Twitter dan juga Facebook, Instagram juga memiliki fitur yang dimana para penggunanya dapat menyinggung pengguna lain yang juga, dengan manambahkan tanda arroba (@) dan memasukkan akun Instagram dari pengguna tersebut. Para pengguna tidak hanya dapat menyinggung pengguna lainnya di dalam judul foto, melainkan juga pada bagian komentar foto. Para pengguna dapat menyinggung pengguna lainnya dengan memasukkan akun Instagram dari pengguna tersebut. Pada dasarnya dalam menyinggung pengguna yang lainnya, yang dimaksudkan adalah untuk berkomunikasi dengan pengguna yang telah disinggung tersebut.

7. Geotagging

Setelah memasukkan judul foto tersebut, bagian selanjutnya adalah bagian Geotag. Bagian ini akan muncul ketika para pengguna iDevice mengaktifkan GPS mereka di dalam iDevice mereka. Dengan demikian iDevice tersebut dapat mendeteksi lokasi para pengguna Instagram tersebut berada.

8. Jejaring Sosial

Dalam berbagi foto, para pengguna juga tidak hanya dapat membaginya di dalam Instagram saja, melainkan foto tersebut dapat dibagi juga melalui jejaring sosial lainnya seperti Facebook, Twitter, Foursquare, Tumblr, dan Flickr yang tersedia di halaman Instagram untuk membagi foto tersebut.

9. Tanda suka (like)

Instagram juga memiliki sebuah fitur tanda suka yang fungsinya memiliki kesamaan dengan yang disediakan Facebook, yaitu sebagai penanda bahwa pengguna yang lain menyukai foto yang telah diunggah. Berdasarkan dengan durasi waktu dan jumlah suka pada sebuah foto di dalam Instagram, hal itulah yang menjadi faktor khusus yang mempengaruhi foto tersebut terkenal atau tidak.

10. Popular (Explore)

Bila sebuah foto masuk ke dalam halaman popular, yang merupakan tempat kumpulan dari foto-foto popular dari seluruh dunia pada saat itu. Secara tidak langsung foto tersebut akan menjadi suatu hal yang dikenal oleh masyarakat 
mancanegara, sehingga jumlah pengikut juga dapat bertambah lebih banyak.

\section{METODE PENELITIAN}

Metode penelitian yang digunakan dalam penelitian ini adalah kualitatif deskriptif dengan pendekatan studi kasus yang fokus pada STRATEGI PUBLIC RELATIONS PT KASOEM HEARING DALAM MEMPUBLIKASIKAN KASOEM EXHIBITION 2018 KEPADA MASYARAKAT INDONESIA.

Menurut Kriyantono "metode studi kasus yaitu metode riset yang menggunakan berbagai sumber data yang bisa digunakan untuk meneliti menguraikan dan menjelaskan secara komprehensif berbagai aspek individu kelompok, suatu program, organisasi atau peristiwa secara sistematis”.(Kriyantono, 2016)

Studi kasus adalah metode riset yang menggunakan berbagai sumber data (sebanyak mungkin data) yang bisa digunakan untuk meneliti, menguraikan, dan menjelaskan secara komprehensif berbagai aspek individu, kelompok, suatu program, organisasi atau peristiwa secara sistematis. Penelaahaan berbagai sumber data ini membutuhkan berbagai macam instrumen pengumpulan data. Karena itu, periset dapat menggunakan wawancara mendalam, observasi partisipan, dokumentasi-dokumentasi, kuesioner (hasil survei), rekaman, bukti-bukti fisik lainnya. (Kriyantono, 2016)

\section{Teknik Pengumpulan Data}

Teknik pengumpulan data dalam penelitian kualitatif adalah dengan melakukan observasi, wawancara mendalam, kepustakaan dan studi dokumentasi.

1. Observasi

Menurut Gibson dan Mitchaell (Maudi, E., 2018) Observasi merupakan teknik yang bisa dimanfaatkan untuk memilah-milah derajat dalam membuat konklusi tentang orang lain, meskipun diakui bahwa penggunaan observasi juga perlu dilengkapi dalam penilaian manusia, dengan demikian observasi dibagi menjadi dua bagian, yaitu:

a. Observasi langsung (Direct Obeservations) Pada kegiatan obeservasi langsung. Peneliti langsung terjun ke lapangan sebagai sasaran penelitian untuk melihat keadaan atau fenomena yang terjadi disana. Dengan begitu, peneliti dapat lebih mengenal karakteristik lokasi, fenomena, dan juga subjek penelitian, dalam hal ini adalah masyarakat yang hendak diteliti.

b. Observasi tidak langsung (Indirect Obesevations)

Observasi tidak langsung merupakan kegiatan pengamatan yang tidak dilakukan pada tempat atau lokasi yang telah ditentukan oleh peneliti. Peneliti dapat menggunakan media, seperti internet, media cetak, rekaman audio visual, dan hasil-hasil penelitian sebelumnya yang memiliki latar permasalahan yang sama dengan yang akan diteliti. (Ardianto, 2011)

Pada penelitian ini penulis menggunakan metode observasi tidak langsung karena penulis malakukan penelitian dengan mengamati media media sosial instagram Museum Nasional Indonesia

2. Wawancara

Esterberg (Sugiyono, 2013)mengemukakan tiga jenis wawancara, yaitu wawancara terstruktur, semistruktur, dan tidak terstruktur.

a. Wawancara terstruktur (structured interview) digunakan sebagai teknik pengumpulan data bila peneliti telah mengetahui dengan pasti tentang informasi apa yang akan diperoleh. Oleh karena itu, dalam melakukan wawancara pewawancara telah menyiapkan instrumen penelitian berupa pertanyaan-pertanyaan tertulis yang alternatif jawabannya pun telah disiapkan. Dengan wawancara terstruktur ini, setiap responden diberi pertanyaan yang sama dan pengumpul data mencatatnya. Dengan wawancara terstruktur ini pula, peneliti dapat menggunakan beberapa pewawancara sebagai pengumpul data. Tentunya, pengumpul data tersebut harus diberi training agar mempunyai kemampuan yang sama.

b. Wawancara semistruktur (semistructure interview) sudah termasuk dalam kategori in-depth interview yang pelaksanaanya lebih bebas bila dibandingkan dengan wawancara terstruktur. Tujuan wawancara jenis ini adalah untuk menemukan permasalahan secara lebih terbuka dan pihak yang diajak wawancara diminta pendapatnya. Dalam melakukan wawancara, peneliti perlu mendengarkan secara teliti dan mencatat apa yang dikemukakan oleh informan.

c. Wawancara tidak berstruktur (unstructured interview) merupakan wawancara yang bebas dan peneliti tidak menggunakan pedoman wawancara yang telah tersusun secara sistematis dan lengkap untuk pengumpulan datanya. Pedoman wawancara yang digunakan hanya berupa garis-garis besar permasalahan yang akan ditanyakan.

Sedangkan pengertian wawancara menurut Setyadin (Gunawan, 2013) "Wawancara adalah suatu percakapan yang diarahkan pada suatu masalah tertentu dan merupakan proses tanya jawab lisan 
dimana dua orang atau lebih berhadapan secara fisik".

Metode wawancara yang digunakan penulis adalah metode wawancara semistruktur. Karena penulis mendengarkan secara teliti dan mencatat apa yang dikemukakan oleh informan.

3. Kepustakaan

Pawito (Ita Suryani1, 2018) menjelaskan bahwa telaah pustaka adalah kajian bersifat kritis atau jelajahan literature (buku-buku, jurnal ilmiah, laporan-laporan penelitian) mengenai berbagai hal, misalnya penjelasan mengenai berbagai hal misalnya penjelasan mengenai konsep-konsep pokok (main cosntrcts) yang digunakan, proposisi-proposisi teoritik mengenai keterkaitan-keterkaitan diantara konsep-konsep, serta temuan-temuan penelitian lain dengan konsep sejenis”.

Dalam hal ini studi kepustakaan yang digunakan penulis dengan mengumpulkan data-data dari buku ilmiah, artikel, dan juga situs.

Menurut Kriyantono studi kepustakaan yaitu "metode riset yang menggunakan berbagai sumber data (sebanyak mungkin data) yang bisa digunakan untuk meneliti, mengurangi, dan menjelaskan secara komperhensif berbagai aspek individu, kelompok, suatu program organisasi atau peristiwa secara sistematis”. (Kriyantono, 2016)

4. Dokumentasi

Menurut Suharsaputra "Dokumen merupakan rekaman kejadian masa lalu yang tertulis atau dicetak mereka dapat berupa catatan anekdot, surat, buku harian, dan dokumen-dokumen”. (Suharsaputra, 2014)

Sedangkan dokumen menurut Sugiyono adalah: Dokumen merupakan catatan peristiwa yang sudah berlalu. Dokumen bisa berbentuk tulisan, gambar, atau karya-karya monumental dari seorang. Dokumen yang berbentuk tulisan misalnya catatan harian, sejarah kehidupan (life histories), ceritera, biografi, peraturan, kebijakan. Dokumen yang berbentuk gambar misalnya foto, gambar hidup, sketsa dan lain-lain. Dokumen yang berbentuk karya misalnya karya seni, yang dapat berupa gambar, patung, film dan lain-lain. Studi dokumen merupakan pelengkap dari penggunaan metode observasi dan wawancara dalam penelitian kualitatif. Dokumentasi dalam penelitian ini diambil dari data dan foto-foto dan arsip-arsip Museum Nasional Indonesia. (Sugiyono, 2013)

\section{HASIL DAN PEMBAHASAN}

Media sosial adalah sebuah media dimana para penggunanya bisa dengan mudah berpartisipasi dan berbagi. Media sosial yang sekarang banyak digunakan adalah Instagram dan facebook.
Instagram bisa mengunggah foto yang lebih bagus dengan filter yang beragam. Selain itu Instagram juga bisa dijadikan sebagai bisnis dan promosi.

Dalam pelaksanaannya, Public Relations PT Kasoem Hearing melibatkan media sosial dalam mempromosikan kegiatan Kasoem Exibitions 2018. PT Kasoem Hearing memakai media sosial instagram dan facebook agar dapat lebih berinteraksi dengan seluruh masyarakat Indonesia, dimana saat ini dua media sosial tersebut diantaranya yang paling diminati oleh masyarakat Indonesia.

Tujuan diadakannya kegiatan Kasoem Exibition adalah untuk menunjukan nilai keunggulan yang dimiliki KASOEM berdasarkan "KEKUATAN" yang dimiliki Perusahaan. Menunjukan bagaimana Kasoem dapat memberikan 'kebahagiaan yang nyata' kepada masyarakat dan mengenal Kasoem secara keseluruhan (booth penjualan hingga service). Kebahagiaan yang nyata tersebut ditunjukkan dalam bentuk acara yang dilaksanakan selama 2 hari berturut turut dengan berbagai macam kegiatan di CTEC Indonesia yang dapat dinikmati dan berguna untuk seluruh masyarakat Indonesia.

Dengan bantuan media sosial, akan semakin banyak masyarakat yang mengetahui tentang kegiatan ini. Tidak hanya masyarakat di Jakarta, tetapi seluruh masyarakat Indonesia akan mengetahui tentang kegiatan Kasoem Exibition 2018 dan membuat masyarakat tertarik untuk berkunjung. Melalui instagram dan facebook publikasi Kasoem Exibition 2018 bisa disebarkan secara cepat dan luas dan masyarakat juga bisa memberikan respon secara cepat, sehingga bisa terjadi komunikasi dua arah yang diharapkan dapat menambahkan ketertarikan masyarakat Indonesia untuk datang.

Berdasarkan hasil wawancara public relations PT Kasoem Hearing, dalam kegiatan ini PT Kasoem Hearing memiliki target utama yaitu seluruh masyarakat Indonesia. Menerapkan publikasi melalui model publikasi modern, memanfaatkan fitur yang ada di dalam Instagram dan Facebook secara maksimal, mengenali sifat pelanggan dan calon pelanggan untuk pemilihan media publikasi yang sedang trend adalah pilihan publikasi yang tepat. Dari beragam fitur pendukung bawaan Instagram dan Facebook tersebut, fitur yang paling sering digunakan pada tiap postingan "Kasoem Exhibition 2018” adalah fitur upload foto dan judul foto. Fitur yang digunakan ini dirasa sangat bermanfaat dalam membantu proses promosi bagi Marketing Communications PT.Kasoem Hearing pada akun Instagram dan Facebook. Seperti upload foto, yang tidak dibatasi seberapa banyaknya foto yang dapat di-upload setiap harinya. Dan melalui Instagram dan Facebook juga acara Kasoem Exhibition 2018 dapat tersampaikan informasi dan diketahui secara luas oleh pelanggan dan calon 
pelanggan. Secara tidak langsung publikasi Kasoem Exhibition 2018 berhasil dan berdampak pula pada penjualan produk pada saat acara berlangsung. Antusias pelanggan dan calon pelanggan pada acara Kasoem Exhibition 2018 sangat terasa dari jumlah pengunjung yang meghadiri acara tersebut. Ini membuktikan bahwa media sosial yang digunakan untuk media publikasi acara berhasil jika strategi yang direncanakan dengan cara yang tepat.

\section{Strategi dan Taktik}

Menurut key informan Bapak Seno Isa Priambodo tujuan dari Public Relations PT. Kasoem Hearing memilih media sosial Instagram dan Facebook sebagai tempat mempublikasi acara secara online adalah karena adanya peluang yang sangat besar dari jumlah pengguna Instagram dan Facebook yang terus meningkat. Staff Public Relations PT Kasoem Hearing juga telah mempelajari beberapa riset yang salah satunya riset dari techinasia, sebuah perusahaan riset dan analisis asal Inggris bernama TNS mencatat bahwa Indonesia menjadi Negara pengguna Instagram terbanyak ketiga di dunia. Sebanyak 89\% pengguna Instagram di Indonesia berusia 18 - 34 tahun.

Berdasarkan laporan digital tahunan yang dikeluarkan oleh We Are Social dan Hootsuite pertumbuhan sosial media tahun ini mencapai 13 persen dengan jumlah pengguna total mencapai 3 miliar. Dari angka tersebut, pengguna Facebook masih mendominasi.Tahun ini, pengguna aktif Facebok tercatat menguasai dua pertiga pasar dengan jumlah pengguna lebih dari 2,17 miliar. Naik 15 persen disbanding tahun sebelumnya. Indonesia menyumban jumlah pengguna Facebook terbesar urutan ke - empat secara global. Hingga Januari 2018, jumlah pengguna Facebook dari Indonesia mencapai 130 juta akun dengan persentase enam persen dari keseluruhan pengguna. Angka ini sekaligus mencatat nama Indonesia sebagai Negara di Asia Tenggara dengan jumlah pengguna Facebook paling banyak. Itulah alas an terkuat Marketing Communications PT Kasoem Hearing memilih melakukan publikasi acara melalui Instagram dan Facebook.

Taktik Digital \& Marketing PT. Kasoem Hearing dalam mencari followers/viewers akun instagram dan facebook PT.Kasoem Hearing adalah dengan memanfaatkan moment giveaway. Selain untuk menggencarkan publikasi Kasoem Exhibition 2018, PT. Kasoem Hearing juga memanfaatkan kegiatan give away ini untuk mencari followers. Biasanya pada setiap giveaway akun @kasoemhearing akan menyertakan syarat kepada peserta untuk memfollow akun Instagram dan Facebook @kasoemhearing dan juga melakukan tag-ing kepada beberapa akun dengan memberi caption menarik yang menginformasikan acara Kasoem Exhibition 2018.

PT. Kasoem Hearing juga mencari followers dengan cara melakukan follow terhadap akun lain. Setelah follow, biasanya mereka akan meminta follow back kepada akun tersebut. Serta bergabung dengan fanpage komunitas para penyandang gangguan pendengaran.

\section{MEDIA}

Public Relations PT Kasoem Hearing menggunakan media sosial instagram dan facebook sebagai media publikasi kegiatan Kasoem Exibition 2018 kepada seluruh masyarakat Indonesia.
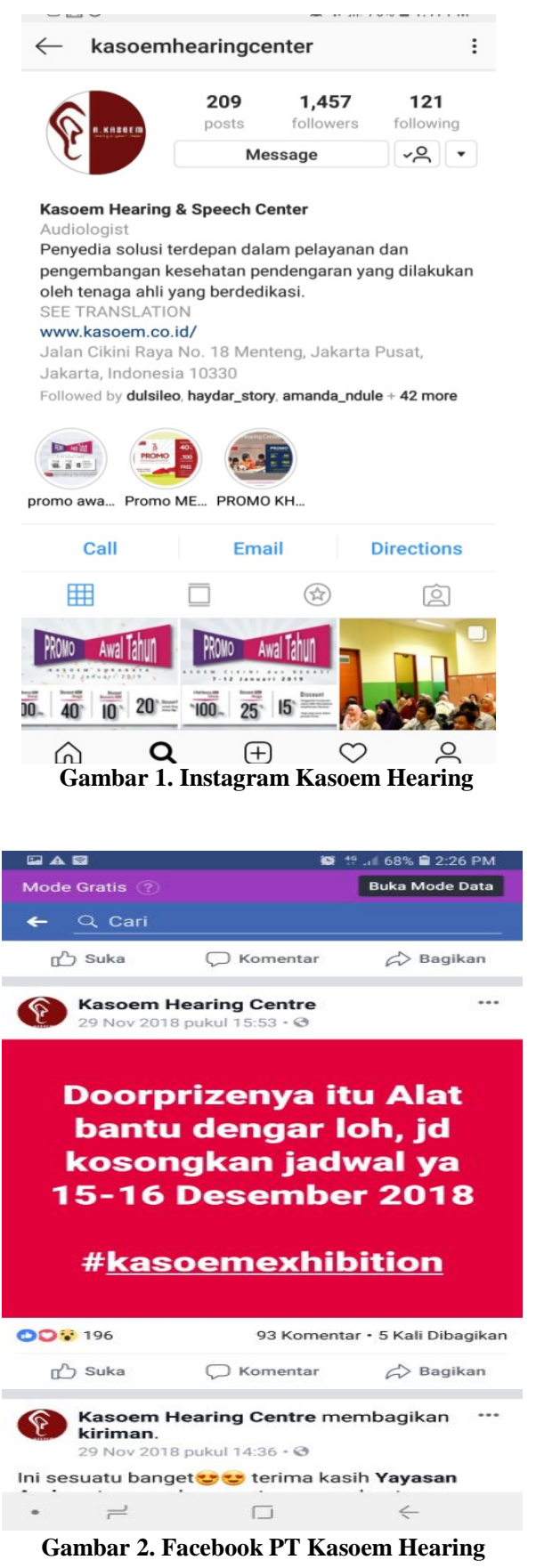


\section{KESIMPULAN}

Dari hasil penelitian mengenai "Strategi Public Relations Dalam Mempublikasikan Kasoem Exhibition 2018 Kepada Pelanggan Dan Calon Pelanggan” dapat disimpulkan sebagai berikut :

Menerapkan publikasi melalui model publikasi modern, memanfaatkan fitur yang ada di dalam Instagram dan Facebook secara maksimal, mengenali sifat pelanggan dan calon pelanggan untuk pemilihan media publikasi yang sedang trend adalah pilihan publikasi yang tepat.

Dari beragam fitur pendukung bawaan Instagram dan Facebook tersebut, fitur yang paling sering digunakan pada tiap postingan "Kasoem Exhibition 2018” adalah fitur upload foto dan judul foto. Fitur yang digunakan ini dirasa sangat bermanfaat dalam membantu proses promosi bagi Marketing Communications PT.Kasoem Hearing pada akun Instagram dan Facebook. Seperti upload foto, yang tidak dibatasi seberapa banyaknya foto yang dapat di-upload setiap harinya. Dan melalui Instagram dan Facebook juga acara Kasoem Exhibition 2018 dapat tersampaikan informasi dan diketahui secara luas oleh pelanggan dan calon pelanggan.

Publikasi Kasoem Exhibition 2018 berhasil dan berdampak pula pada penjualan produk pada saat acara berlangsung. Antusias pelanggan dan calon pelanggan pada acara Kasoem Exhibition 2018 sangat terasa dari jumlah pengunjung yang meghadiri acara tersebut. Ini membuktikan bahwa media sosial adalah pilihan yang tepat untuk melakukan publikasi kegiatan Kasoem Exibition 2018.

\section{REFERENSI}

Giantika, G. G. (2018). Pemanfaatan Vlog Sebagai Komunikasi Interpersonal (Studi Deskriptif Kualitatif Album Ke-7 Endank Soekamti "Soekamti Day"). Jurnal Komunikasi, 9, 15-23. Retrieved from http://ejournal.bsi.ac.id/ejurnal/index.php/jko $\mathrm{m} /$ article/view/3539/2292

Gunawan, I. (2013). Metode Penelitian Kuantitatif: Teori dan Praktik. Jakarta: PT Bumi Aksara.

Ita Suryani, A. S. (2018). STRATEGI KOMUNITAS BETAWI DALAM MEMPROMOSIKAN TRADISI PALANG PINTU (Studi Kasus Pada Event Festival Palang Pintu XI). Jurnal Komunikasi, 8, 2-7. Retrieved from http://ejournal.bsi.ac.id/ejurnal/index.php/jko m/article/view/2497/1730

Kriyantono, R. (2016). Public Relations Writing. Jakarta: Prenadamedia.

Kussanti, D. P., \& Leliana, I. (2018). Efektifitas
Program Employee Relations Terhadap Motivasi Kerja 2an PT Adira Dinamika Multifinance. Cakrawala, 2, 179-184.

Maudi, E., \& S. (2018). Strategi Koperasi Karya Mandiri Dalam Memperkenalkan Product Knowledge Melalui Event Gowes Pesona Nusantara. Jurnal Komunikasi, 9, 31-38. Retrieved from http://ejournal.bsi.ac.id/ejurnal/index.php/jko $\mathrm{m} / \mathrm{article} / \mathrm{view} / 3592$

Ruslan, R. (2013). Metode Penelitian: Public Relations dan Komunikasi. Jakarta: Rajawali Pers.

Soraya, I. (2018). Personal Branding Laudya Cynthia Bella Melalui Instagram (Studi Deskriptif Kualitatif Pada Akun Instagram @Bandungmakuta). Jurnal Komunikasi, 9, 31-38. Retrieved from http://ejournal.bsi.ac.id/ejurnal/index.php/jko m/article/view/2654/1804\%0A

Sugiyono. (2013). Metode Penelitian Kuantitatif, Kualitatif dan R\&D. Bandung: CV Alfabeta.

Suharsaputra, U. (2014). Metode Penelitian Kuantitatif, Kualitatif dan Tindakan. Bandung: PT Refika Aditama.

Susilowati. (2018). Kegiatan Humas Indonesia Bergerak Di Kantor Pos Depok II Dalam Meningkatkan Citra Instansi Pada Publik Eksternal. Jurnal Komunikasi, 8, 47-54. Retrieved from http://ejournal.bsi.ac.id/ejurnal/index.php/jko $\mathrm{m} /$ article/view/2686/1815

\section{PROFIL PENULIS}

Silvina Mayasari, S.Sos, M.Si lahir di Padang, 12 Maret 1981 adalah seorang Dosen Program Studi Hubungan Masyarakat di Fakultas Komunikasi dan Bahasa Universitas Bina Sarana Informatika (UBSI). Memulai karirnya di Universitas BSI sejak September 2009. Menyelesaikan Pendidikan S1 di Jurusan Jurnalistik Fakultas Komunikasi Institut Ilmu Sosial dan Ilmu Politik (IISIP) Jakarta pada tahun 2003, dan menyelesaikan Pendidikan S2 Magister Ilmu Komunikasi di Sekolah Pascasarjana Universitas Sahid pada tahun 2016. Penulis saat ini juga tergabung dalam Ikatan Sarjana Komunikasi Indonesia (ISKI).

Mareta Puri rahastine S.Sn, M.I.Kom lahir di Jakarta, 15 Maret 1988 adalah seorang dosen Program Studi Hubungan Masyarakat di Fakultas Komunikasi dan Bahasa Universitas Bina Sarana Informatika (UBSI) sejak Maret 2012. Menyelesaikan S1 di Universitas Pasundan Bandung Jurusan Design Komunikasi Visual (DKV) pada tahun 2011. Dan Selesai S2 di Universitas Mercubuana Jurusan Komunikasi konsentrasi Corporate And Marketing Communication pada tahun 2015. 
Annisa Qibtiah adalah mahasiswa Fakultas Komunikasi dan Bahasa Program Studi Hubungan Masyarakat Universitas BSI Jakarta. Lahir di Jakarta, 12 September 1997. Penulis giat dalam melakukan pendidikan akademik dan melakukan penelitian. 